\title{
PENYULUHAN KESEHATAN TENTANG PENTINGNYA TABLET TAMBAH DARAH PADA REMAJA PUTRI DI DESA UWUNG GIRANG, TANGERANG
}

\author{
Siti Haeriyah ${ }^{1)}$, Nurry Ayuningtyas Kusumastuti1) \\ 1)Program Studi Kebidanan STIKes Yatsi Tangerang, Banten, Indonesia \\ Corresponding author : Siti Haeriyah \\ E-mail : shaeriyah381@gmail.com
}

Diterima 09 Mei 2021, Direvisi 22 Mei 2021, Disetujui 25 Mei 2021

\begin{abstract}
ABSTRAK
Permasalahan yang terjadi pada remaja putri salah satunya adalah Anemia karena kurang nya tablet tambah darah ( $\mathrm{Fe}$ ) yang dapat melemahkan kesehatan, mengalami gangguan perkembangan otak dan sistem kekebalan tubuh yang rendah, sehingga kegiatan belajar di sekolahnya dapat terganggu. Oleh karena itu perlu diberikan tablet tambah darah ( $\mathrm{Fe}$ ) dan diedukasi juga dampak anemia. Target pemberian tablet tambah darah secara nasional adalah $10 \%$ remaja putri dengan dosis pencegahan yaitu remaja putri (10-19 tahun) atau WUS (15- 45 tahun) sehari 1 tablet tiap minggunya, jadi total tablet tambah darah ( $\mathrm{Fe}$ ) yang akan diterima oleh remaja putri adalah 13 tablet selama 4 bulan. Upaya untuk mengurangi dampak anemia pada remaja putri yaitu dengan adanya Penyuluhan kesehatan yang bertujuan untuk meningkatkan pengetahuan dan pemahaman tentang pentingnya tablet tambah darah (Fe). Penyuluhan kesehatan dilakukan dengan metode ceramah. Hasil kegiatan penyuluhan kesehatan dengan memberikan pre test didapatkan saat pre test yang terbanyak dengan pengetahuan rendah sebanyak 18 responden (60\%) dan setelah diberikan penyuluhan kesehatan didapatkan pengetahuan baik meningkat menjadi 24 responden (80\%). Dapat diartikan bahwa adanya peningkatan $60 \%$ pengetahuan responden setelah diberikan penyuluhan kesehatan. Oleh karena itu diperlukan penyuluhan kesehatan agar remaja putri mengerti pentingnya tablet tambah darah.
\end{abstract}

Kata kunci: penyuluhan kesehatan; tablet tambah darah; remaja Putri

\begin{abstract}
One of the problems that occur in young women is anemia. because the lack of Fe supplementation can weaken health, impaired brain development and low immune system, so that learning activities at school become disrupted. Therefore it is necessary to give Fe supplementation. Other than that, young women must also be educated about the impact of anemia. The target of giving fe supplementation tablet nationally is $10 \%$ young women with a preventive dose that is young women (10-19 years) or women of childbearing age (15- 45 years) a day 1 tablet per week, so the total Fe supplementation that will be received by young women. Efforts to reduce the impact of anemia on young women namely the existence of health education which aims to increase knowledge and understanding of the importance of Fe supplementation. Health education is conducted by lecturing method. Results of health education activities during the most pre-test with low knowledge as many as 18 respondents (60\%) and after being given health education good knowledge increased to 24 respondents $(80 \%)$. and can be interpreted that there is an increase of $60 \%$ of respondents' knowledge after being given health education. This shows that needed for health education so they would understand the Fe supplementation
\end{abstract}

Keywords:. health dducation; fe supplementation; young women

\section{PENDAHULUAN}

Saat ini ada empat masalah gizi pada remaja di Indonesia adalah Kekurangan Energi Protein (KEP), Anemia Gizi Besi (AGB), Gangguan Akibat Kekurangan Yodium (GAKI), dan Kekurangan Vitamin A (KVA). Diantara empat masalah gizi diatas yang sering terjadi sampai saat ini adalah AGB pada remaja putri. (Almatsier, 2009)

Prevalensi nasional kejadian anemia di Indonesia berdasarkan data Riskesdas (2013), yaitu mencapai $21,7 \%$. Proporsi kejadian anemia di Indonesia menurut karakteristik jenis kelamin perempuan lebih mendominasi jika dibandingkan dengan laki-laki, presentasi pada perempuan $23,9 \%$ dan laki-laki $18,4 \%$ serta berdasarkan karakteristik kelompok umur 5-14 tahun lebih tinggi jika dibandingkan dengan remaja umur 15- 21 tahun, pada umur 5-14 tahun $26,4 \%$ kejadian anemia dan umur 15-21 tahun $18,4 \%$ kejadian anemia. (Kemenkes RI, 2013) 
Program pemerintah pada pemberian tablet tambah darah bagi remaja kembali digalakkan dengan target pemberiannya pemberian tablet penambah darah $(\mathrm{Fe})$ bagi remaja putri yang duduk di kelas VIII SMP dan XI SMA sekitar 6.000 sasaran dalam program ini. Tablet penambah darah akan diberikan satu butir per minggu selama empat bulan hingga November. Fakta dilapangan tablet tambah darah yang menjadi salah satu alternatif untuk menanggulangi anemia di lapangan hanya berfokus pada ibu hamil saja, sedangkan untuk remaja putri belum dilakukan secara maksimal. (Dinas Kesehatan Bandung, 2016)

Penelitian Akib \& Sumarni (2017), bahwa asupan zat gizi responden yang terdiri dari karbohidrat, protein, vitamin $\mathrm{C}$ dan mineral $\mathrm{Fe}$, sebagian besar memiliki tingkat asupan yang kurang. Kurangnya tingkat asupan zat gizi responden antara lain dipengaruhi oleh kebiasaan makan yang melewatkan satu maupun dua waktu makan bahwa rata-rata responden memiliki pola konsumsi makanan pokok 2x sehari dan menggantinya dengan kebiasaan mengkonsumsi makanan selingan.(Akib \& Sumarmi, 2017)(Martini, 2015)

Penelitian Martini (2015) faktor yang mempengaruhi kejadian anemia yaitu status gizi dan tingkat pendidikan ibu. Status gizi dalam kategori kurus mempunyai risiko 3,1 kali mengalami anemia dibandingkan dengan remaja yang status gizinya normal dan ibu yang berpendidikan rendah, kurang memperhatikan makanan yang dikonsumsi anaknya dan kurang memperhatikan pemenuhan kebutuhan gizi seimbang. Bagi keluarga dengan tingkat pendidikan yang tinggi akan lebih mudah menerima informasi kesehatan dan mampu menerapkan dalam kehidupan sehari-hari. Anemia pada remaja dapat membawa dampak kurang baik bagi remaja, anemia yang terjadi dapat menyebabkan menurunnya kesehatan reproduksi, perkembangan motorik, mental, kecerdasan terhambat, menurunnya prestasi belajar, tingkat kebugaran menurun, dan tidak tercapainya tinggi badan maksimal. (Martini, 2015)

Dengan adanya permasalahan di atas, maka dilakukanlah pengabdian ini dengan tujuan untuk memberikan penyuluhan kesehatan tentang tablet tambah darah diharapkan remaja putri dapat meningkatkan pengetahuan dan pemahaman terhadap dampak anemia yang dapat menyebabkan gangguan perkembangan otak dan sistem kekebalan tubuh yang rendah, sehingga kegiatan belajar di sekolahnya menjadi terganggu. Oleh karena itu perlu minum tablet tambah darah $(\mathrm{Fe})$ yang tinggi zat besi.

\section{METODE}

Metode yang digunakan pada kegiatan ini adalah Metode ceramah yang disampaikan kepada remaja putri Di Desa Uwung Girang, Kecamatan Cibodas, Tangerang.

Langkah-langkah yang dilakukan pada kegiatan ini antara lain: 1) Persiapan. Menyiapkan bahan pengabdian masyarakat. Sebelum penyuluhan kesehatan dilaksanakan terlebih dahulu penyuluh membuat Power point dan Leafleat tentang penting nya Tablet tambah darah dan dampak buruk anemia pada remaja putri serta membuat kuesinoer pre test post test dan leafleat pentingnya tablet tambah darah. Leafleat ini terdiri dari definisi anemia, tanda tanda anemia, dampak anemia, pencegahan anemia, tablet tambah darah. 3) Pelaksanaan kegiatan dengan memberikan penyuluhan kesehatan. Pada pengabdian masyarakat ini responden berjumlah 30 remaja putri. Sebelum dilakukan penyuluhan remaja putri diberikan kuesioner pre test dengan jumah 10 pertanyaan. selanjutnya diberikan Penyuluhan pada remaja putri tentang pentingnya tablet tambah darah. Penyuluhan ini dilakukan 1 kali pada dengan waktu yang sudah ditentukan oleh ketua RT yaitu pada tanggal 23 agustus 2020 yang diadakan di Rumah ketua RT Desa Uwung Girang, Kecamatan Cibodas, Tangerang. Materi penyuluhan diberikan oleh penyuluh, dengan waktu 120 menit dan setelah diberikan penyuluhan remaja putri diberikan kuesioner post test. Adapun panitia dan pelaksana dari kegiatan ini adalah 2 orang dosen Prodi Kebidanan serta 2 orang mahasiswa prodi Kebidanan Stikes Yatsi Tangerang.4). melakukan monitoring dengan mengumpulkan mengolah dan menganalisa data berupa kuesioner yang telah diberikan kepada remaja putri 5) Evaluasi. Hasil yang diperoleh menunjukan bahwa ada nya peningkatan pengetahuan pada remaja putri setelah di berikan penyuluhan kesehatan tentang pentingnya tablet tambah darah.

\section{HASIL DAN PEMBAHASAN}

Berdasarkan kegiatan yang dilakukan pada remaja putri di Desa Uwung Girang, Kecamatan Cibodas, Tangerang. Kegiatan yang dilakukan ini adalah penyuluhan tentang pentingnya tablet tambah darah agar dapat meningkatkan pengetahuan dan pemahaman remaja putri. Hasil Pelaksanan ini ditunjukan dalam tabel distribusi tingkat pengetahuan remaja putri pada tabel 1 . 
Tabel 1. Distribusi pengetahuan remaja putri tentang pentingnya TTD $(n=30)$

\begin{tabular}{lcccc}
\hline $\begin{array}{c}\text { Tingkat } \\
\text { Pengetahuan }\end{array}$ & $\begin{array}{c}\text { Pre } \\
\text { test }\end{array}$ & $\%$ & $\begin{array}{c}\text { Post } \\
\text { test }\end{array}$ & $\%$ \\
\cline { 2 - 5 } & $\mathbf{n}$ & $\%$ & $\mathbf{n}$ & $\%$ \\
\hline Baik & 6 & $20 \%$ & 24 & $80 \%$ \\
\hline Cukup & 6 & $20 \%$ & 4 & $13,33 \%$ \\
\hline Kurang & 18 & $60 \%$ & 2 & $6,67 \%$ \\
\hline Total & $\mathbf{3 0}$ & $\mathbf{1 0 0} \%$ & $\mathbf{3 0}$ & $\mathbf{1 0 0} \%$
\end{tabular}

Sumber : Data diolah

Berdasarkan hasil kegiatan penyuluhan tentang pentingnya tablet tambah darah yang telah dilaksanakan dan didapatkan pengetahuan remaja putri tentang pentingnya tablet tambah darah sebelum penyuluhan (Pre Test) yang terbanyak dengan pengetahuan rendah sebanyak 18 responden (60\%), dibandingkan dengan setelah diberikan penyuluhan. Hasil pelaksanaan kegiatan penyuluhan kesehatan pada remaja putri didapatkan tingkat pengetahuan tentang pentingnya tablet tambah darah setelah penyuluhan (Post Test) terbanyak pada pengetahuan baik ada 24 responden $(80 \%)$.

Pengetahuan adalah salah satu faktor yang mempengaruhi perubahan perilaku kesehatan remaja dalam mencegah anemia, selain pengetahuan menurut teori Lawrence Green menyatakan bahwa terdapat beberapa faktor yang mempengaruhi perubahan perilaku seseorang diantaranya peran tenaga kesehatan, tradisi dan motivasi. (Notoatmodjo, 2012)

Kurangnya informasi akan berpengaruh terhadap pengetahuan seseorang. Semakin sering terpapar informasi maka pengetahuan seseorang akan meningkat pula. (Made \& Mahayati, 2019)

Menurut penyuluh bahwa terdapat peningkatan pengetahuan setelah penyuluhan tentang pentingnya tambah darah karena kegiatan penyuluhan berlangsung kondusif sehingga informasi yang disampaikan dapat diterima dengan baik oleh responden.

\section{SIMPULAN DAN SARAN}

Penyuluhan kesehatan mengenai pentingnya tablet tambah darah memberikan dampak terhadap peningkatan pengetahuan dan pemahaman remaja putri. Hal ini terlihat adanya peningkatan pengetahuan baik $(60 \%)$ pada remaja putri setelah dilakukan penyuluhan kesehatan mengenai pentingnya tambah darah. Oleh karena itu, informasi mengenai tablet tambah darah sangatlah penting untuk mengubah pola pikir remaja putri.
Salah satu upaya dengan melakukan penyuluhan kesehatan mengenai pentingnya tablet tambah darah pada remaja putri agar remaja putri mengerti dan memahami akan kesehatan mereka. Diharapkan kegiatan penyuluhan ini lakukan secara terus menerus agar dapat meningkatkan pengetahuan dan kesadaran remaja putri sehingga tidak ada lagi remaja putri yang mengalami anemia. diharapkan masyarakat dan pemerintah dapat memberikan fasilitas dalam pemberian tablet tambah darah secara merata diwilayah tersebut.

\section{UCAPAN TERIMAKASIH}

Ucapan terima kasih kepada Yasasan Afiyat, Ketua STIKes Yatsi, Ketua Penelitian dan Pengabdian kepada Masyarakat (LPPM) STIKes Yatsi Tangerang, tim pengabdian masyarakat, dan berbagai pihak yang terlibat dalam kegiatan pengabdian masyarakat

\section{DAFTAR RUJUKAN}

Akib, A., \& Sumarmi, S. (2017). Kebiasaan Makan Remaja Putri yang Berhubungan dengan Anemia : Kajian Positive Deviance Food Consumption Habits of Female Adolescents Related to Anemia: A Positive Deviance Approach. Amerta Nutrition, 1(2), 105-116. https://doi.org/10.20473/amnt.v1.i2.2017. 105-116

Almatsier. (2009). Prinsip Dasar IImu Gizi (Cetakan IX). Gramedia.

Dinas Kesehatan Bandung. (2016). Siswi di Kota Bandung Bisa Dapat Tablet Penambah Darah Hari Ini. ttps://www.pikiran-rakyat.com/bandungraya/pr-01261669/siswi-di-kota-bandungbisa-dapat-tablet-penambah-darah-hariini-376641

Kemenkes RI. (2013). Riset Kesehatan Dasar.

Made, N., \& Mahayati, D. (2019). MANFAAT PENYULUHAN DENGAN MEDIA LEAFLET.

Martini. (2015). Faktor Yang Berhubungan dengan anemia pada remaja putri di MAN 1 METRO. 8(3), 149-157.

Notoatmodjo. (2012). Promosi Kesehatan dan Perilaku Kesehatan. Rineka Cipta. 